\title{
Agronomic performance of hard endosperm Opaque-2 corn populations in Puerto Rico'
}

\author{
Linda Wessel-Beaver, César Cardona Castro, Paul R. Hepperly ${ }^{2, s}$
}

\begin{abstract}
Six hard endosperm (modified) opaque-2 (02) corn populations from CIMMYT were compared with local corn cultivars Diente de Caballo and Mayorbela. Grain yield, days to $50 \%$ anthesis, plant and ear height, endosperm modification, and lodging were measured. Diente de Caballo was very late in flowering, whereas Mayorbela was earlier than the mean of the 02 genotypes. Diente de Caballo and Mayorbela were taller than 02 genotypes; thus they were more susceptible to lodging. Diente de Caballo was higher yielding than 02 genotypes, but Mayorbela ranked among the lowest yielders at all locations. The magnitude of the local $x$ genotype variance suggests that multiple location testing would be needed to distinguish between yield and degree of modification of different genotypes. Other traits studied could be tested at one location.
\end{abstract}

\section{INTRODUCTION}

Local pork and poultry industries produce nearly a third of the consumer demand for their products (1). Considerable expansion of these industries should be possible. Corn is the principal component of local feed and feed concentrates. If corn could be produced economically, the above mentioned industries would provide a ready market.

Because of the low levels of the amino acids lysine and tryptophan found in corn protein swine and poultry nutrition requires proper feed supplements. The high lysine/tryptophan corn mutant opaque-2 (o2) improves nutrition in monogastric animals, such as poultry and swine over that from normal corn $(2,4)$. The 02 gene produces a soft opaque phenotype unlike that of normal hard translucent kernels $(3,6)$. CIMMYT and others have improved this undesirable phenotype by using modifier genes that change the 02 endosperm to a normal or near normal phenotype while maintaining high lysine levels $(5,6)$.

The objective of this research was to evaluate the agronomic potential of six hard endosperm 02 corn populations from CIMMYT and to compare them to two traditional Puerto Rican cultivars.

'Manuscript submitted to Editorial Board 15 September 1987.

${ }^{2}$ Associate Plant Breeder, Department of Agronomy and Soils; Former Graduate Research Assistant; and Research Plant Pathologist, USDA-ARS, TARS, formerly Associate Plant Pathologist, Department of Crop Protection.

'The 1983 data was part of the second author's Master's thesis. The authors thank Carmen Teresa Ramírez, Luis Ernesto Rivera, Luz González, and Raúl Pérez for their technical assistance. This research was supported in part by the U.S. Department of Agriculture under CSRS Special Grant No. 82-CRSR-2-221 bxx-CRSR-X-XXXX managed by the Caribbean Basin Advisory Group (CBAG). 


\section{MATERIALS AND METHODS}

Six hard endosperm 02 corn populations from CIMMYT were compared with the two local cultivars, Diente de Caballo and Mayorbela in five trials in Lajas and Isabela in 1983, and in Lajas, Islabela, and Fortuna in 1984 (table 1). In the 1984 trials, selected versions (one cycle (C1) of $\mathrm{S} 1$ family recurrent selection) of two 02 populations, Amarillo Cristalino and Tuxpeño-1 QPM, were also included.

A randomized complete block design with three and four replicates was used in the 1983 and 1984 trials, respectively. The trials were planted on 17 March 1983 in Lajas, 25 May 1983 in Isabela, 23 July 1983 in Isabela 24 July 1984 in Fortuna, and 10 August 1984 in Lajas. The trials were planted on a Fraternidad clay (Vertisol), a San Antón clay loam (Molisol), and a Coto clay (Oxisol) at Lajas, Fortuna, and Isabela, respectively. In $1983,340 \mathrm{~kg} / \mathrm{ha}$ of 15-5-10 fertilizer was incorporated before planting; in $1984,560 \mathrm{~kg} / \mathrm{ha}$ of $10-10-10$. At 6 weeks $225 \mathrm{~kg} / \mathrm{ha}$ of nitrogen (urea) was sidedressed. In most trials, Furadan 10G (2,3 dihydro-2,2-di-methyl-7 benzafuranyl methylcarbamate) for insect control, and Lasso [4-amino-6(1,1-dimethylethyl)-3-(methylthio)-1,2,3-triazin-5(4H)-one)] for weed control were preplant-incorporated at a rate of $34 \mathrm{~kg} / \mathrm{ha}$, and $7 \mathrm{~L} / \mathrm{ha}$, respectively. The 1983 trials were planted in $5.1 \mathrm{~m}$ rows of $0.9 \mathrm{~m}$ apart with plants spaced at $25 \mathrm{~cm}(+43,400$ plants per hectare). Plots were four rows wide. The center rows except for end plants were harvested. The 1984 trials were planted in $8.1 \mathrm{~m}$ rows and $0.9 \mathrm{~m}$ apart with plants spaced at $20 \mathrm{~cm}(+53,800$ plants per hectare). Plots were seven rows wide. Plots were irrigated as needed. The inner five rows except for the end plants were harvested.

Plant height (ground to flag leaf) and ear height (ground to node of uppermost ear) and days to $50 \%$ anthesis [50\% of plants in plot shedding pollen) were recorded. Plots were hand harvested and mechanically shelled. Grain yield was adjusted to $15.5 \%$ moisture (wet weight basis). In the 1983 trial, percentage endosperm modification was recorded 0 to $100 \%$ translucent) following Wessel-Beaver and Lambert (6). Degree of endosperm modification was determined on a 0 (completely opaque kernels to 5 (completely normal and translucent kernels) scale.

Analyses of variance were carried out for individual locations. A Bartlett's test of homogeneity indicated that variances were not homogenous when all five envirnoments were combined, but were homogeneous over locations within years with certain exceptions (percentage modification, days to anthesis in 1983, and grain yield in 1984). Only combined analyses are presented since results at individual locations were similar even when variances were heterogenous. Locations and entries were considered fixed effects. An $F$-test protected least significant difference (F-LSD), and non-orthogonal single degree of freedom comparisons were used to compare treatment means. 
TABLE 1.-Description of corm populations and cultivars

\begin{tabular}{|c|c|c|c|c|c|}
\hline Genotype $^{1}$ & Origin & $\begin{array}{l}\text { Endosperm } \\
\text { color }\end{array}$ & $\begin{array}{l}\text { Endosperm } \\
\text { type }\end{array}$ & $\begin{array}{l}\text { Years } \\
\text { tested }\end{array}$ & Comments \\
\hline Mayorbela & Puerto Rico & Yellow & Normal & 1983,1984 & Flint; traditional type \\
\hline Amarillo Cristalino QPM C1 & CIMMYT & Yellow & Modified 02 & 1984 & $\begin{array}{l}\text { Dent; converted from normal } \\
\text { grain type }\end{array}$ \\
\hline Amarillo Dentado-1 QPM & CIMMYT & Yellow & Modified 02 & 1983,1984 & Dent; converted from norma \\
\hline Amarillo Dentado-2 QPM & CIMMYT & Yellow & Modified o2 & 1983,1984 & Dent; converted from normal \\
\hline Pool-23 QPM & CIMMYT & White & Modified o2 & 1983,1984 & Flint; late maturing \\
\hline White H. E. 02 & CIMMYT & White & Modified o2 & 1983,1984 & $\begin{array}{l}\text { Hard endosperm types } \\
\text { selected from White } 02\end{array}$ \\
\hline
\end{tabular}

${ }^{1}$ QPM is CIMMYT's notation for "quality protein maize". $\mathrm{C} 0$ and $\mathrm{C} 1$ refer to the original and first cycle after S1 recurrent selection, respectively. 
TABLE 2.-Significance of F-test in analyses of variance of modified opaque and normal genotypes combined over locations within 1988 and 1984 trials

\begin{tabular}{|c|c|c|c|c|c|c|c|c|c|c|c|c|c|}
\hline Source of Variation & \multicolumn{2}{|c|}{$\begin{array}{c}\text { Degrees of } \\
\text { freedom }\end{array}$} & \multicolumn{2}{|c|}{$\begin{array}{c}\text { Modification } \\
\text { Percent Degree }\end{array}$} & \multicolumn{2}{|c|}{$\begin{array}{l}\text { Days to } 50 \% \\
\text { anthesis }\end{array}$} & $\begin{array}{l}\begin{array}{l}\text { Percent } \\
\text { lodging }^{1}\end{array} \\
1984\end{array}$ & \multicolumn{2}{|c|}{$\begin{array}{l}\text { Plant height } \\
(\mathrm{cm})\end{array}$} & \multicolumn{2}{|c|}{$\begin{array}{l}\text { Ear height } \\
\text { (cm) }\end{array}$} & \multicolumn{2}{|c|}{$\begin{array}{c}\text { Gain yield } \\
\text { (kg/ha) }\end{array}$} \\
\hline Location & 1 & 2 & NS & NS & $* * 2$ & $* * *$ & - & $* *$ & $*$ & $*$ & $*$ & NS & *** \\
\hline Genotype $^{3}$ & 7 & 9 & $*$ & $*$ & $*$ & $* *$ & $* *$ & $* *$ & $* *$ & $* *$ & $* *$ & NS & $* *$ \\
\hline Location x Geno. & 7 & 18 & NS & * & NS & NS & - & $* *$ & $* *$ & $* *$ & $* *$ & $\mathrm{NS}$ & $*$ \\
\hline
\end{tabular}

${ }^{3}$ Percentage lodging measured only at Fortuna with 3 and 9 degrees of freedom for block and entry effects.

$2 *$ ** Mean square significant at the 0.05 and 0.01 probability levels, respectively.

${ }^{3}$ Modified opaque-2 populations and normal cultivars. 


\section{RESULTS AND DISCUSSION}

Locations within trial years were different except for endosperm modification and grain yield in 1983 trials (table 2 ). The five environments tested offered a range of conditions resulting in differences in location means for most traits (table 3). Conditions in these environments were representative of those found in the coastal plains of Puerto Rico, except no trials were in progress during the coolest months, January and February.

Significant differences among genotypes (populations or cultivars) were found for all traits during both years except for 1983 grain yield (tables 2 and 4). Location by genotype interaction was significant for degree of endosperm modification in 1983, plant and ear height in both years, and grain yield in 1984 (table 2). For plant and ear height and percentage modification, the genotype effect was greater than the location $x$ genotype interaction. Rankings of means were similar at all locations. For grain yield and degree of endosperm modification, the interaction variance was similar in magnitude to genotypes. These two traits would require testing over locations to distinguish between genotypes.

In the combined analyses of variance of both years, the genotype effect was partitioned into non-orthogonal single degree of freedom com parisons. The $F$-tests of these comparisons along with the corresponding genotype means help to compare 02 populations with the normal cultivars

TABLE 3.-Location means of modification, days to anthesis, plant and ear height, and grain yield averaged over all populations and cultivars ${ }^{1}$

\begin{tabular}{|c|c|c|c|c|c|c|}
\hline \multirow{2}{*}{$\begin{array}{l}\text { Loeation within } \\
\text { trial year }\end{array}$} & \multicolumn{2}{|c|}{ Modification } & \multirow{2}{*}{$\begin{array}{c}\text { Days to } 50 \% \\
\text { anthesis }\end{array}$} & \multirow{2}{*}{$\begin{array}{l}\text { Plant height } \\
\quad(\mathrm{cm})\end{array}$} & \multirow{2}{*}{$\begin{array}{l}\text { Ear height } \\
\text { (cm) }\end{array}$} & \multirow{2}{*}{$\begin{array}{c}\text { Grain yield } \\
\text { (kg/ha) }\end{array}$} \\
\hline & Percent & Degree & & & & \\
\hline $\begin{array}{l}\text { Lajas } 1983 \\
\text { (March-August) }\end{array}$ & 98.3 & 4.2 & 60.6 & 155.5 & 70.9 & 3194 \\
\hline $\begin{array}{l}\text { Isabela } 1983 \\
\text { (May-October) }\end{array}$ & 98.6 & 4.3 & 55,1 & 188.9 & 82.7 & 3580 \\
\hline$F$-LSD (1983 Trial) ${ }^{2}$ & NS & NS & 1.7 & 18.0 & 13.0 & NS \\
\hline $\begin{array}{l}\text { Lajas } 1984 \\
\text { (August-January) }\end{array}$ & - & - & 57.3 & 177.8 & 96.6 & 4316 \\
\hline $\begin{array}{l}\text { Isabela } 1984 \\
\text { (July-December) }\end{array}$ & 一 & - & 62.7 & 179.1 & 97,2 & 3387 \\
\hline $\begin{array}{l}\text { Fortuna } 1984 \\
\text { (July-December) }\end{array}$ & - & - & 55.3 & 190.2 & 107.6 & 3984 \\
\hline$F$-LSD (1984 Trials) $)^{2}$ & - & - & 1.2 & 11.7 & 10.9 & 451 \\
\hline
\end{tabular}

' Location means averaged over six 02 populations and two normal cultivars in 1983 , and over eight 02 and two normal cultivars in 1984.

${ }^{2} F$-test protected least significant difference for location means at the 0.05 probability level. LSD not calculated for location means are not significantly different in $F$-test. 
TABLE 4.-Means of endosperm modification, days to 50\% anthesis, plant and ear height, and grain yield for six modified endosperm opaque-2 populations and two normal local cultivars averaged over two locations in 1983 and three locations in 1984

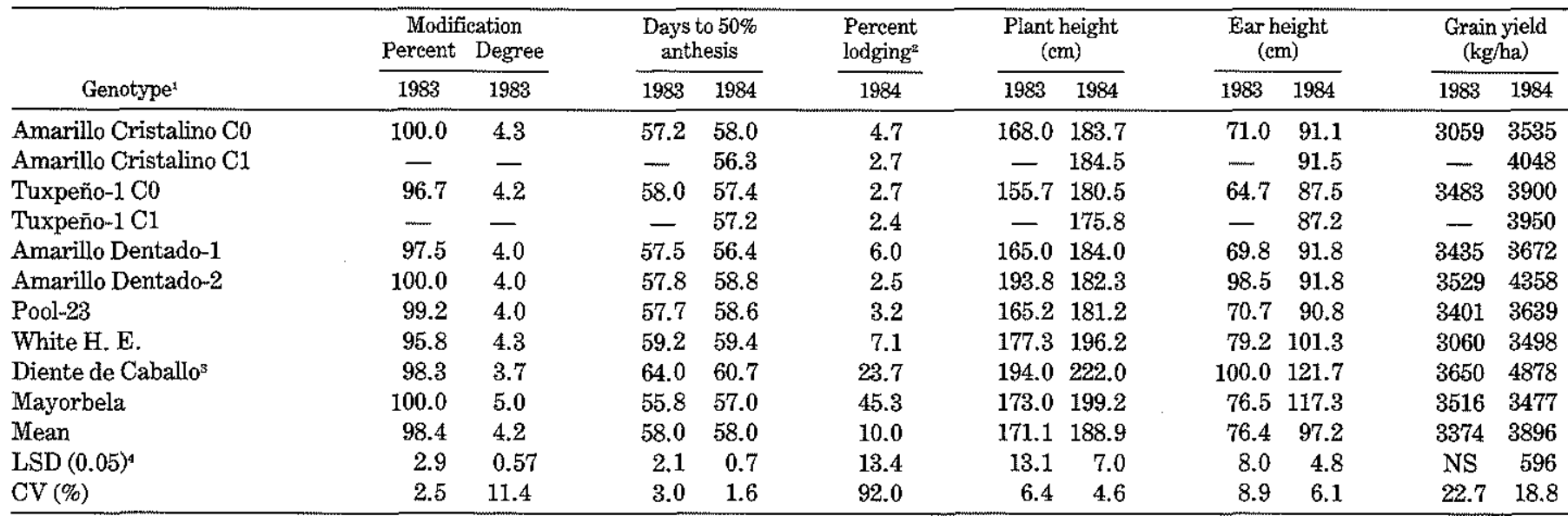

${ }^{1}$ Cycle $1(\mathrm{C} 1)$ of Amarillo Cristalino and Tuxpeno-1 not included in 1983 trial. Means are of two locations and three replications in 1983 and three locations and four replications in 1984.

${ }^{2}$ Measured in 1984 at Fortuna only.

31983 means are of three replications in Lajas only.

${ }^{4} F$-test protected least significant difference at the 0.05 probability level. LSD not calculated for entry means not significantly different in $F$-test. 
TABLE 5.-Single degree of freedom comparisons among six modified opaque-2 populations and two normal (non opaque-2) cultivars averaged over two locations in 1983 and three locations in 1984

\begin{tabular}{|c|c|c|c|c|c|c|}
\hline \multirow[b]{3}{*}{ Comparison (1983 trial) } & \multicolumn{6}{|c|}{ Mean squares } \\
\hline & \multicolumn{2}{|c|}{ Modification } & \multirow{2}{*}{$\begin{array}{c}\text { Days to } 50 \% \\
\text { anthesis }\end{array}$} & \multirow{2}{*}{$\begin{array}{l}\text { Plant height } \\
\text { (cm) }\end{array}$} & \multirow{2}{*}{$\begin{array}{l}\text { Ear height } \\
\text { (cm) }\end{array}$} & \multirow{2}{*}{$\begin{array}{c}\text { Grain yield } \\
(\mathrm{kg} / \mathrm{ha})\end{array}$} \\
\hline & Percent & Degree & & & & \\
\hline $0-2$ vs. local cultivars & 8.5 & 0.34 & $37.0^{* * 1}$ & $3802.8^{\text {*1:*** }}$ & $5017.4^{* * *}$ & 585863 \\
\hline o-2 vs. Diente de Caballo & 0.1 & $1.15^{*}$ & $192.1 \%$ & $3649.5^{* * *}$ & $4040.0^{* * *}$ & 533968 \\
\hline o-2 vs. Mayorbela & 16.8 & $3.81^{* *}$ & $21.7^{*}$ & $1077.2^{* *}$ & $1894.8^{* * *}$ & 181877 \\
\hline Diente de Caballo vs. Mayorbela & 8.3 & $5.33^{* \% *}$ & $200.1^{* * *}$ & $444.1^{1 \div *}$ & $234.1^{*}$ & 54002 \\
\hline \multirow[t]{2}{*}{ Error (1983 trial) $)^{2}$} & 6.2 & 0.23 & 3.1 & 121.9 & 46.0 & 636406 \\
\hline & \multicolumn{2}{|c|}{$\begin{array}{c}\text { Days to } 50 \% \\
\text { anthesis }\end{array}$} & $\begin{array}{l}\text { Percent } \\
\text { lodging }\end{array}$ & $\begin{array}{l}\text { Plant height } \\
\text { (cm) }\end{array}$ & $\begin{array}{l}\text { Ear height } \\
\text { (cm) }\end{array}$ & $\begin{array}{c}\text { Grain yield } \\
(\mathrm{kg} / \mathrm{ha})\end{array}$ \\
\hline Amarillo Cristalino (C0 vs. C1) & \multicolumn{2}{|c|}{$16.67 * *$} & 7.6 & 4.2 & 1.0 & 1580553 \\
\hline Tuxpeño-1 (C0 vs. C1) & \multicolumn{2}{|c|}{0.37} & 0.2 & 135.4 & 0.4 & 15150 \\
\hline Unselected o-2 vs. local cultivars & \multicolumn{2}{|c|}{$9.39 * *$} & $25116.5^{* * *}$ & $12090.1^{* *}$ & $13230.2^{* * *}$ & 3034416 \\
\hline Selected $0-2$ vs. local cultivars & \multicolumn{2}{|c|}{$52.08^{*} *$} & $4080.0^{* * *}$ & $11132.5^{* * *}$ & $10890.2^{* * *}$ & 496541 \\
\hline o-2 vs. local cultivars & \multicolumn{2}{|c|}{$21.69 \%$} & $6002.5 \% *$ & $14050.9 * *$ & $14907.6^{* *}$ & $2385861 \%$ \\
\hline Unselected o-2 vs. Diente de Cabalio & \multicolumn{2}{|c|}{$67.17^{* * *}$} & $5770.5^{* 2 *}$ & $14336.0^{* *}$ & $8816.8^{* * *}$ & $12697778^{* *}$ \\
\hline Unselected o-2 vs. Mayorbela & \multicolumn{2}{|c|}{$12.69 \%$} & $1283.7^{* * * *}$ & $2162.6^{* * *}$ & $6400.0^{* * *}$ & 864531 \\
\hline Diente de Caballo vs. Mayorbela & \multicolumn{2}{|c|}{$161.33^{* *}$} & $939.6^{* *}$ & $3128.2^{* * *}$ & 112.7 & $23553612^{* * *}$ \\
\hline Error (1984 trial) $)^{2}$ & \multicolumn{2}{|c|}{0.82} & 85.2 & 74.8 & 34.8 & 539090 \\
\hline
\end{tabular}


(tables 4 and 5). Only comparisons for combined analyses are presented since repartitioning of individual analyses gave similar results.

No differences in percentage endosperm modification (a measure of translucency) were observed between normal vs. 02 genotpyes (table 5). All genotypes exhibited greater than $95 \%$ modification (i. e., at least $95 \%$ of the kernels had some translucent or modified sector in their endosperm (table 4). There were more differences observed for degree of endosperm modification (tables 4 and 5). This trait measures the average amount of modification or translucency in individual kernels on an ear. Diente de Caballo showed the least translucency even though it is non-opaque because of its floury endosperm. Mayorbela exhibited the common "normal" (ie completely translucent) phenotype. The 02 genotypes were intermediate and Amarillo Cristalino was the most highly modified.

The 02 populations were intermediate in flowering, on the average, compared to the local cultivars (tables 4 and 5). Diente de Caballo was very late to flower, whereas Mayorbela was slightly earlier than the average of the 02 populations. Selection for earlier flowering was generally effective. Flowering was earlier in Amarillo Cristalino subjected to selection (C1) than in the unselected (C0) population. A similar but nonsignificant trend was observed in Tuxpeño-1.

The 02 genotypes were shorter with the top ear positioned lower than the local varieties (tables 4 and 5). Diente de Caballo was the tallest genotype in every trial. The most striking difference between the 02 and local genotypes is seen in percentage lodging. Data was collected from the 1984 trial in Fortuna (table 4 and 5). This high fertility environment dramatically showed the susceptibility of tall local cultivars to lodging. Severe lodging in the local cultivars was also observed in other trials. No difference in plant and ear height and lodging was observed between $\mathrm{CO}$ and $\mathrm{C} 1$ of Amarillo Cristalino and Tuxpeño-1.

Both the 02 and local genotypes produced similar grain yields in the 1983 trials, but the 02 genotypes yielded lower than Diente de Caballo in the 1984 trials (tables 4 and 5). Mayorbela was among the lowest yielders in all trials. No improvement in yield was observed after one cycle of selection in Amarillo Cristilano and Tuxpeño-1.

\section{CONCLUSION}

Although within trial years location had a large effect upon most traits, the differences of the gonotype by location interaction were generally either non-significant, of the same magnitude as the gentype effect, or did not affect genotype rankings. Ranking of means of grain yield and degree of endosperm modification was affected by location, and thus should be tested in multiple environments.

Modified 02 populations were similar to normal (non o2) local cultivars for most traits. Grain yield of the 02 populations was generally less than 
that of Diente de Caballo but equal to or greater than that of Mayorbela. The 02 populations were shorter and more lodging resistant than the local cultivars. With some improvement in grain yield, 02 populations such as Amarillo Cristalino or Amarillo Dentado could be agronomically superior to local open pollinated cultivars with the added benefit of higher lysine levels. Corn needs considerable cost-return analysis before it can be recommended as a viable crop in Puerto Rico. Local prices of feed grains are higher than in the continental U.S., but production costs are higher and yields generally lower than in the U. S. corn belt.

\section{RESUMEN}

Comportamiento agronómico de poblaciones de maíz de endospermo duro derivadas de "opaque-2" en Puerto Rico

Se compararon seis siembras de maíz opaco-2 (02) con endospermo duro (modificado) de CIMMYT con dos cultivares locales, Diente de Caballo y Mayorbela. Se midieron el rendimiento, días para $50 \%$ de antesis, alfura de la planta y de la mazorca, modificación del endospermo y acamado de las plantas. Diente de Caballo fue muy tardío en florecer mientras que Mayorbela espigó más temprano que el promedio de los genotipos 02 . Diente de Caballo y Mayorbela eran más altos, y por ende más susceptibles al acamado. Diente de Caballo produjo un rendimiento más elevado que los genotipos 02, mientras que Mayorbela estuvo entre los de menor rendimiento en todas las localidades. La magnitud de la varianza de la interacción de la localidad $X$ el genotipo sugiere que sería necesaria la experimentación en diferentes localidades para distinguir entre rendimiento y grado de modificación de diferentes genotipos. Otros rasgos prodrían estudiarse en una sola localidad.

\section{LITERATURE CITED}

1. Department of Agriculture, 1985. Facts and Figures on Puerto Rico's Agriculture, 198485. Office of Aggicultural Statistics. Santurce, P. R.

2. Eggum, B. O., E. M. Villegas and S. K. Vasal, 1979. Progress in protein quality of maize. J. Sci. Food 30:1148.

3. Mertz, E. T., L. S. Bates and 0. E. Nelson, 1964. Mutant gene that changes protein composition and increases lysine content of maize endosperm. Science 145:279-80.

4. Pinstrup-Anderson, P., 1971. The feasibility of introducing opaque-2 maize for human consumption. Tech. Bull., No. 1, Centro Internacional de Agricultura Tropical (CIAT), Cali, Columbia.

5.Vasal, S. K., E. Villegas, M. Bjarnason, B. Gelaw and P. Goertz, 1980. Genetic modifiers and breeding strategies in developing hard endosperm opaque-2 materials. p. 37-73. In W. E. Polloner and P. H. Phipps (Eds) Improvement of quality traits of maize for grain and silage use. Martinus Nijhoff Publ. The Hague, The Netherlands.

6. Wessel-Beaver, L. and R. J. Lambert, 1982. Genetic control of modified endosperm texture in opaque-2 maize. Crop Sci. 22:1095-098. 